\title{
Foot Rot of Gerbera Caused by Phytophthora cryptogea Pethyb. \& Laff. in Japan
}

\author{
Etsuo KIMISHIMA* and Masaaki GoTo*
}

Key words : Phytophthora cryptogea, gerbera, foot rot.

In February, 1984, destructive foot rots of gerbera (Gerbera jamesonii Bolus) were observed in a glasshouse for nursery stocks at Fujisawa, Kanagawa Pref., Japan. A foot rot of gerbera was reported in 1969 in Japan by Morita ${ }^{8}$, who attributed the cause to an unidentified species of Phytophthora. This paper reveals the species of causal fungus of the disease. A brief report of this work has been published elsewhere ${ }^{4)}$.

Symptoms. The main diagnostic symptoms of the disease consisted of sudden wilting of the leaves accompanied by a conspicuous color change from normal green to dark violet. Affected crown and root tissues were soft, water-soaked, rotted and blackish brown in color. These were similar to the symptoms caused by Phytophthora sp. reported previously ${ }^{8}$.

Diagnosis. Enzyme-linked immunosorbent assay ${ }^{2)}$ (ELISA) was applied to diagnose the disease of the symptomatic plants. An antiserum prepared for Phytophthora erythroseptica Pethyb. showing genus specific reactivities ${ }^{3}$ was used. The preparation of antigen samples and the procedures of ELISA were performed as previously described ${ }^{5}$. Extracts of the diseased parts of the gerbera reacted with Phytophthora antibody. Healthy parts used as control gave no positive reaction. The serological test using ELISA indicated that this disease might be caused by Phytophthora.

Isolation and identification. Affected leaf tissues were washed and cut into pieces. They were placed on a selective medium for Phytophthora ${ }^{6)}$ and incubated at $25^{\circ} \mathrm{C}$ for 3 days. After incubation, hyphal tips on the selective medium were transferred onto water agar for single hyphal tippings. Isolates were cultured on V-8 agar (V-8: $200 \mathrm{ml}$ Campbell V-8 juice, $2.5 \mathrm{~g}$ calcium carbonate, $15 \mathrm{~g}$ agar per liter). Representative isolate, SG-1 (=IFO 32325), was used for describing the morphology. To study the production of sex organs, the amended V-8) (aV-8: $200 \mathrm{ml} \mathrm{V-8} \mathrm{juice,} 30 \mathrm{mg} \beta$-sitosterol, $20 \mathrm{mg}$ tryptophane, $100 \mathrm{mg} \mathrm{CaCl} \cdot 2 \mathrm{H}_{2} \mathrm{O}, 1 \mathrm{mg}$ thiamine, and $15 \mathrm{~g}$ agar per liter) was used. SG-1 was paired with each A1 mating type isolate of $P$. cryptogea Pethyb. \& Laff.** (University of California, Riverside: UCR, Collection P1738) and P. cinnamomi Rands** (UCR, Collection P2138 and P3664), paired also with each A2 mating type isolate of $P$. cryptogea** (UCR, Collection P3850) and P. cinnamomi** (UCR, Collection P2457 and P2392), or grown alone on $\mathrm{aV}-8$ at $15^{\circ} \mathrm{C}$ for 2 weeks.

Young hyphae had no septa, but became septate with age. On V-8, the fungus exhibited no characteristic pattern and clusters of hyphal swellings were ovserved. Cardinal growth temperatures on $\mathrm{V}-8$ were as follows: minimum below $5^{\circ} \mathrm{C}$, optimum $25-30^{\circ} \mathrm{C}$, and maximum $33^{\circ} \mathrm{C}$. Typical sporangia were frequently found on the diseased plant tissues in water (Fig. 1-A and B). Sporangia (av. $44.4 \times 29.3$ $\mu \mathrm{m}$, range $62.5-20.0 \mu \mathrm{m} \times 37.5-12.5 \mu \mathrm{m}, \mathrm{L} / \mathrm{B}$ ratio=1.51) were non-papillate, non-deciduous, ovoid obpiliform or ellipsoidal, and internal proliferation and sympodial elongation occurred. This isolate resembled Phytophthora sp. reported by Morita ${ }^{8)}$ according to the sporangia and cardinal growth temperatures. Sex organs were not produced in single culture but were produced only when paired with A1 mating type isolates of $P$. cryptogea and P. cinnamomi. Oogonia (av. $35.5 \mu \mathrm{m}$, range $25-45 \mu \mathrm{m}$ ) in dual cultures were spherical with smooth walls and becoming yellowish with age. Antheridia (av. 15 $\mu \mathrm{m}$ ) were amphigynous, spherical, occasionally oval. Oospore (av. $30.1 \mu \mathrm{m}$, range 20-40 $\mu \mathrm{m}$ ) nearly filled the oogonium (Fig. 1-C).

* Yokohama Plant Protection Station, Naka-ku, Yokohama 231, Japan 横浜植物防疫所

** Import permit number issued by Ministry of Agriculture, Forestry and Fisheries is 1Y1952. 

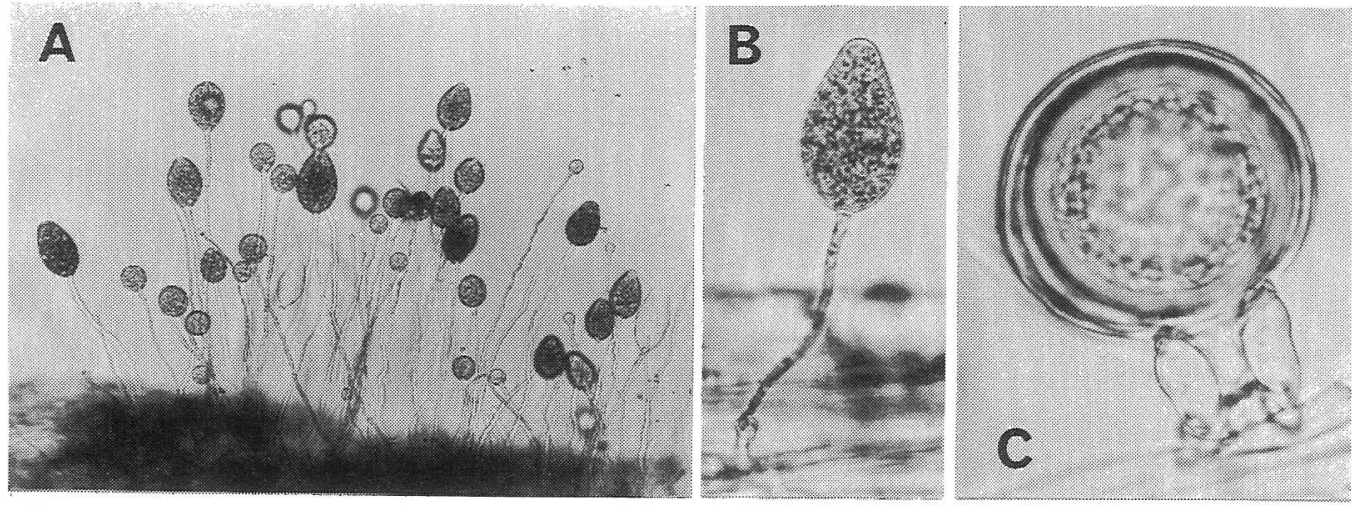

Fig. 1. Morphology of Phytophthora cryptogea causing foot rot of gerbera. A: non-papillate sporangia that developed on the China-aster seedling flooded with water $(\times 110)$; B: typical sporangium $(X$ 330); C: oogonium with amphigynous antheridium and oospore $(\times 800)$.

Table 1. Effect of temperature on oospore production of P. cryptogea (SG-1) in the amended V-8 agar ${ }^{\mathrm{a})}$

\begin{tabular}{|c|c|c|c|}
\hline \multirow{3}{*}{ Temperature $\left({ }^{\circ} \mathrm{C}\right)$} & \multicolumn{3}{|c|}{ Oospore production rating ${ }^{\mathrm{b})}$} \\
\hline & \multirow{2}{*}{$\frac{\text { P. cryptogea }}{\text { P } 1738}$} & \multicolumn{2}{|c|}{ P. cinnamomi } \\
\hline & & P 2138 & P 3664 \\
\hline 10 & ++ & ++ & + \\
\hline 15 & ++ & ++ & + \\
\hline 20 & ++ & ++ & + \\
\hline 25 & - & - & - \\
\hline 30 & - & - & - \\
\hline
\end{tabular}

a) SG-1 was paired with A1 mating type isolates of $P$. cryptogea and $P$. cinnamomi.

b) The rating $(-: 0,+: 1-10$, and $++:$ more than 10$)$ was based on the mean number of oospores observed in microscope field (about $2.5 \mathrm{~mm}^{2}$ ).

Table 2. Production of oospores of $P$. cryptogea (SG-1) in various media after 2 weeks at $15^{\circ} \mathrm{C}^{\mathrm{a}}$ )

\begin{tabular}{|c|c|c|c|}
\hline \multirow{3}{*}{ Mediab) } & \multicolumn{3}{|c|}{ Oospore production rating ${ }^{c)}$} \\
\hline & \multirow{2}{*}{$\frac{\text { P. cryptogea }}{\text { P } 1738}$} & \multicolumn{2}{|c|}{ P. cinnamomi } \\
\hline & & P 2138 & P 3664 \\
\hline HSA & ++ & ++ & + \\
\hline CMA & ++ & + & + \\
\hline $\mathrm{V}-8$ & ++ & + & + \\
\hline $\mathrm{aV}-8$ & ++ & ++ & + \\
\hline PSA & - & - & - \\
\hline
\end{tabular}

a) See foot note a) in Table 1 .

b) HSA, CMA, V-8, aV-8 and PSA=hemp seed agar, corn meal agar, V-8 agar, amended V-8 agar and potato sucrose agar, respectively, described in text.

c) See foot note b) in Table 1 .

From the above results, the isolate was identified as Phytophthora cryptogea Pethyb. \& Laff..$^{10,11)}$ which has been known as a foot rot fungus of gerbera in USA ${ }^{12)}$ and Europe ${ }^{9}$, and was isolated from an alfalfa-field soil, in Hokkaido, Japan ${ }^{7}$.

Effects of temperature and culture media on oospore formation. SG-1 was paired with $P$. cryptogea (P1738) and P. cinnamomi (P2138 and P3664) on aV-8 in the petri dishes and then placed in the incubators of $10-30^{\circ} \mathrm{C}$ at $5^{\circ} \mathrm{C}$ intervals to determine the effect of temperature. To determine the effect of medium, dual cultures were incubated at $15^{\circ} \mathrm{C}$ on the following media: V-8, aV-8, corn meal agar (CMA: $20 \mathrm{~g}$ corn meal, $15 \mathrm{~g}$ agar per liter), hemp seed agar (HSA: $100 \mathrm{~g}$ hemp seed, $15 \mathrm{~g}$ agar per liter), 


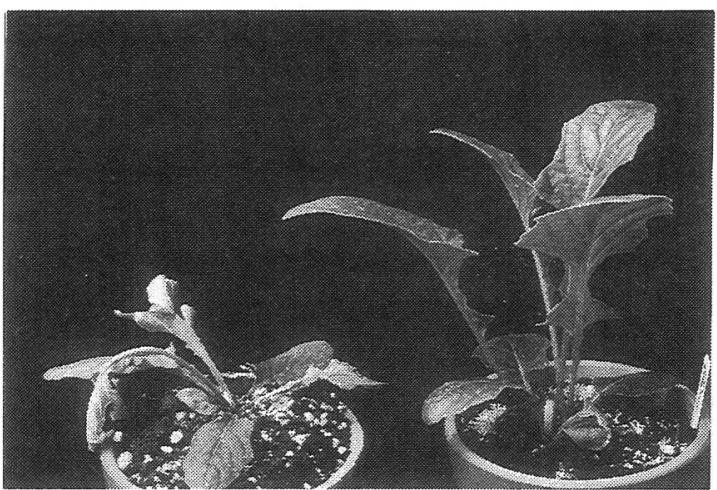

Fig. 2. Diseased gerbera grown in the artificially infested soil with $P$. cryptogea (left) and healthy gerbera grown in the uninfested soil (right).

potato sucrose agar (PSA: $200 \mathrm{~g}$ potato, $20 \mathrm{~g}$ sucrose, $15 \mathrm{~g}$ agar per liter). After 2 weeks the bottom of the petri dishes was examined under the microscope and oospores were counted.

Abundant oospores were produced at 15 and $20^{\circ} \mathrm{C}$, but no oospore was found at higher temperatures than $25^{\circ} \mathrm{C}$ (Table 1 ), though the optimum temperature for vegetative growth was $25-30^{\circ} \mathrm{C}$. SG-1 produced oospores in V-8, aV-8, CMA and HSA, but no oospore was observed in PSA (Table 2).

Pathogenicity. The pathogenicity of SG-1 was tested several times to the following seedlings by the method described elsewhere): gerbera, China-aster (Callistephus chinensis Nees), stock (Matthiola incana R. Br.), godetia (Godetia grandiflora Lindl.), Chinese cabbage (Brassica campestris L.), corn poppy (Papaver rhoeas L.), snapdragon (Antirrhinum majus L.), sweet pepper (Capsicum annuum L.), tomato (Lycopersicon esculentum Mill.), pumpkin (Cucurbita maxima Duch.) and cucumber (Cucumis sativus L.). SG-1 was highly pathogenic to gerbera (Fig. 2), China-aster and stock (100-76\% killed), moderately pathogenic to Chinese cabbage, corn poppy and snapdragon (51-27\% killed), weakly pathogenic to sweet pepper and tomato (7-2\% killed) and non-pathogenic to pumpkin and cucumber. The fungus was consistently reisolated from the diseased plants.

The present paper reveals that $P$. cryptogea is the causal agent of foot rot of gerbera reported by Morita $^{8)}$ in Japan.

We wish to thank Dr. H. Morita, Dr. T. Nishio and Mr. Y. Kobayashi for their helpful advice, and Dr. B. Gabor, University of California, Riverside, for providing the isolates of $P$. cryptogea and $P$. cinnamomi. Thanks are also to Dr. T. Kobayashi for critical reading of the manuscript.

\section{Literature cited}

1. Chee, K.H., Zentmyer, G.A., Foong, K.M. and Klure, L.J. (1976). Mating types of Phytophthora palmivora in Malaysia. Pl. Dis. Reptr. 60: 866-867.

2. Clark, M.F. and Adams, A.N. (1977). Characteristics of the microplate method of enzyme-linked immunosorbent assay for the detection of plant viruses. J. gen. Virol. 34: 475-483.

3. Kimishima, E., Kobayashi, Y. and Nishio, T. (1989). Serological reactivities of antisera prepared for four Phytophthora spp. Res. Bull. Pl. Prot. Japan 25 : 1-6 (in Japanese).

4. Kimishima, E. and Goto, M. (1991). Foot rot of gerbera caused by Phytophthora cryptogea. Ann. Phytopath. Soc. Japan 57 : 76-77 (Abstr. in Japanese).

5. Kimishima, E., Kobayashi, Y. and Nishio, T. (1991). Root rot of carnation caused by Pythium irregulare and P. aphanidermatum. Ann. Phytopath. Soc. Japan $57: 534-539$.

6. Masago, H., Yoshikawa, M., Fukada, M. and Nakanishi, N. (1977). Selective inhibition of Pythium spp. on a medium for direct isolation of Phytophthora spp. from soils and plants. Phytopathology $67: 425-428$.

7. Matsumoto, N. and Sato, T. (1979). Phytophthora cryptogea Pethyb. \& Laff. found in alfalfa-field soil. Ann. Phytopath. Soc. Japan $45: 362-368$.

8. Morita, H. (1969). Diseases of gerbera and their control. Nougyo oyobi Engei 44 : 1270-1272 (in Japanese). 
9. Smith, I.M., Dunez, J., Lelliott, R.A., Phillips, D.H. and Archer, S.A. (1988). European Handbook of Plant Diseases. Blackwell Scientific Publications, Great Britain. pp. 208-209.

10. Stamps, D.J. (1978). Phytophthora cryptogea. CMI Descriptions of Pathogenic Fungi and Bacteria No. 592.

11. Stamps, D.J., Waterhouse, G.M., Newhook, F.J. and Hall, G.S. (1990). Revised tabular key to the species of Phytophthora. Mycological Papers (IMI) 162 : 1-28.

12. Tompkins, C.M. and Tucker, C.M. (1937). Foot rot of China-aster, annual stock and Transvall daisy caused by Phytophthora cryptogea. J. agric. Res. $55: 563-574$.

\section{和 文 摘 要}

君島悦夫・後藤正昭：わが国における Phytophthora cryptogea Pethyb. \& Laff.によるガーベラ根腐病について

1984 年 2 月, 神奈川県藤沢市内のガーベラ栽培温室内で, 根腐病（Phytophthora sp.）とみられる被害が発生した。 被害株はP. erythroseptica 抗血清を用いた ELISA 試験で顕著な反応を示した。分離菌は土䁃接種でガーべラをはじめ 多くの植物に病原性を示した。本菌は P. cryptogea 及び P. cinnamomi の A1 菌株との対峙培養により有性器官を生じ た。形態的特徵から分離菌を P. cryptogea Pethyb. \& Laff. と同定した。本試験によりガーベラ根腐病の病原菌が明ら かになった。

(Received May 18, 1991) 